\title{
Forests dynamics in the montane-alpine boundary: a comparative study using satellite imagery and climate data
}

\author{
Lucian Dinca ${ }^{1}$, Mihai Daniel Nita ${ }^{2, *}$, Annika Hofgaard ${ }^{3}$, Concepcion L. Alados ${ }^{4}$, \\ Gabriele Broll ${ }^{5}$, Stelian Alexandru Borz ${ }^{2}$, Bogdan Wertz $^{6}$, Antonio T. Monteiro ${ }^{7}$
}

\author{
${ }^{1}$ National Forest Research-Development Institute, Cloșca 13, Brașov, 500040, Romania \\ ${ }^{2}$ Faculty of Silviculture and Forest Engineering, Transilvania University of Brasov, Ludwig van Beethoven 1, Brașov, 500123, \\ Romania \\ ${ }^{3}$ Norwegian Institute for Nature Research, Høgskoleringen 9, 7034 Trondheim, Norway \\ ${ }^{4}$ Pyrenean Institute of Ecology (CSIC), Av. Ntra. Sra. de la Victoria, Huesca, 22700, Spain \\ ${ }^{5}$ University of Osnabrück, Neuer Graben, 49074 Osnabrück, Germany \\ ${ }^{6}$ University of Agriculture, Faculty of Forestry, Adama Mickiewicza 21, Kraków, 30-001, Poland \\ ${ }^{7}$ Predictive Ecology Group, Research Center on Biodiversity and Genetic Resources, CIBIO-InBIO, Rua Padre Armando \\ Quintas 7, Vairão, 4485-661, Portugal
}

\begin{abstract}
Over the past decades, the altitudinal and latitudinal advance of forest lines has increased due to global warming and the abandonment of less productive areas previously subject to agricultural activities. The intensity and speed of the forest line advance also depend on numerous physical, biological and human factors that are region-specific. It is important to fully understand the mechanisms behind forest line behaviour, as existing studies do not report global figures. We selected 4 study areas in which to analyse the temporal and spatial behaviour of the forest line and of forest cover based on selection criteria such as minimal human interference and maximal representativeness at the European level. The sites were located in national parks that were evenly spread across some of the dominant European mountain ranges such as the Pyrenees, Alps and Carpathians, at comparable altitudes and latitudes, and with similar land cover proportions in the year 1970. Methodologically, we used cloud-free Landsat satellite images that were acquired in the same month during the growing season. A post-classification comparison technique, using all bands but the thermal one, was implemented to evaluate forest line behaviour, while the accuracy of image classification was evaluated by random sampling. Four time frames were used to evaluate forest cover behaviour in relation to the non-forested areas: 1971-1980, 1981-1990, 1991-2000 and 2001-2014. Also, climate and topography data were included in this study, which enabled comparison and computation of dependence relations. Our results indicate significant differences between the analysed areas. For instance, for the same reference period (1981-1990), the greatest differences in terms of forest cover change were specific to the Austrian Alps $(28 \%)$, whereas the lowest differences were those from the Spanish Pyrenees (1\%). Similar forest line shifts were found in the Austrian Alps and in the Romanian Carpathians, whereas the lowest altitudinal advancement was specific to the Spanish Pyrenees. According to this study, the temperature trend could have significantly influenced tree line behaviour.
\end{abstract}

KEY WORDS: Remote sensing $\cdot$ Tree lines $\cdot$ Mountains $\cdot$ National park

\section{INTRODUCTION}

Forested areas are increasing in many developed countries due to the combined effects of more inten-

*Corresponding author: mihai.nita@unitbv.ro

${ }^{\S}$ Advance View was available online April 13, 2017 sive agriculture, abandonment of less productive areas and increasing awareness regarding the environmental importance of forests (Müller et al. 2009, Kozak 2010, Lambin \& Meyfroidt 2010, Baumann et restricted. Authors and original publication must be credited. 
al. 2011). In mountainous afforested areas, the dynamics in the montane-alpine belts, namely in the tree and forest lines (limit of uppermost $>2 \mathrm{~m}$ tall trees, and limit of continuous forest [canopy cover of $>10 \%$, respectively), are particularly relevant. Here, climate influences ecological processes governing dynamics in forest stands, but human land use has also been a control factor for centuries (Gehrig-Fasel et al. 2007). Owing to the climatic influence on the tree and forest lines, they are regarded as environmental change descriptors. In Europe, changes in these boundaries have been observed (Gehrig-Fasel et al. 2007) and the discussion on whether these changes are related to human land use or climate is ongoing. Therefore, it is in the public interest to monitor forest changes within the montane-alpine belts, and evaluate their relationship with altered climatic features, particularly if multiple sites are considered, allowing comparisons on a continental scale.

In general, information on changes in mountain forest cover is not always publicly accessible. There is still a lack of comprehensive knowledge of spatially and temporally explicit forest cover dynamics, especially across large areas and at sufficient spatial detail to resolve the full range of forest change processes (Griffiths et al. 2014). However, the technology that enables full global monitoring and better comprehension of the various properties of forest resources is evolving, for instance the increasing availability of remote sensing data. Satellite remote sensing is frequently used to assess land ecosystem dynamics, as it provides consistent measurements of bio-geophysical processes, including natural and anthropogenic disturbances (Jin \& Sader 2005, Linderman et al. 2005). The synoptic and regular coverage at short intervals of consistent remote sensing data provides a valuable source for updated land cover information necessary to monitor the type and extent of environmental changes (Mas 1999). The Landsat archive is among the most used data sources for studying land cover changes, including deforestation, agricultural expansion and intensification, urban growth, and wetland loss (Coppin \& Bauer 1996, Woodcock et al. 2001, Seto et al. 2002, Galford et al. 2008, Gartzia et al. 2014), due to its long record of continuous measurement, spatial resolution and near-nadir observations (Pflugmacher et al. 2012, Wulder et al. 2012). For forests, these data have been providing spatial and spectral details, allowing the capture of forest attributes at adequate scales for analysis since the 1970s (Griffiths et al. 2014). More recently, continental or even global data analyses with Landsat are feasible, due to advances in auto- mated imagery pre-processing and processing methods, and data storage capabilities (Townshend et al. 2012). For instance, Hansen et al. (2008) produced 2 regional Landsat composites that aimed to detect forest changes in the Congo Basin, also integrating the MODIS Vegetation Continuous Field product (Hansen et al. 2003) for classified training purposes. Potapov et al. (2011) focused on boreal forest changes between 2000 and 2005 in European Russia, using composited Landsat data, and independently obtained indicators of forest change. For mountain tree line and forest line monitoring, Wang et al. (2006) proposed a Landsat satellite-based monitoring that considers the temporal response of continuous vegetation indices (e.g. normalised difference vegetation index), while Klinge et al. (2015) combined Landsat image classification and spatial modelling to understand the distribution patterns. Both studies used multi-temporal image analysis. Dynamics of mountain tree lines and forest lines vary across the globe. Previous studies reveal an average northward advance of 156 and $71 \mathrm{~m}$ for birch and pine forest lines in Norway during the 20th century, respectively (Hofgaard et al. 2013). Shifts in tree lines were more pronounced in birch $\left(340 \mathrm{~m} \mathrm{yr}^{-1}\right)$, whereas pine advance was very limited $\left(10 \mathrm{~m} \mathrm{yr}^{-1}\right)$. In Russia's Khibiny Mountains, the mean tree line advance of birch and pine was 29 and $27 \mathrm{~m}$ in altitude (0.6 and $0.5 \mathrm{~m} \mathrm{yr}^{-1}$ ), respectively, between 1958 and 2008 (Mathisen et al. 2014). In the Italian Alps, tree lines shifted upwards by $115 \mathrm{~m}$ between 1901 and 2000 (Leonelli et al. 2011). Overall, analysis of historical and recent forest delineation data shows a very restricted advance rate compared to the predictions of dynamic global vegetation models (ACIA 2005, Kaplan \& New 2006).

Complex interactions between factors affects the patterns of mountain tree lines (e.g. exposure to wind, snow depth, animals, mass outbreak of insects) and forest lines. Tree line responses to climate change are dependent on a multitude of interacting abiotic and biotic drivers in a site-specific manner (Holtmeier \& Broll 2005, Holtmeier 2009, Hofgaard et al. 2012), with characteristics determined by multiple variables (Holtmeier \& Broll 2007, Hofgaard et al. 2012), dominated by temperature, precipitation, wind and herbivory (Sveinbjörnsson et al. 2002, Cairns \& Moen 2004, Holtmeier \& Broll 2005). A change in the regeneration capacity in the tree line ecotone has caused its main features, forest line, tree line and species line (limit of tree saplings and seedlings) to move back and forth over time in accordance with long- and short-term climate changes 
(Dalen \& Hofgaard 2005, Payette 2007, Shiyatov et al. 2007, Holtmeier \& Broll 2010, Chhetri \& Cairns 2015).

Ameztegui et al. (2015) parameterised and used an individual based, spatially explicit model of forest dynamics (SORTIE-ND) to investigate the role of species-specific differences in juvenile performance induced by climate change (juvenile growth and recruitment ability) in the dynamics of mixed forests located in the montane-subalpine ecotone of the Pyrenees. Batllori \& Gutiérrez (2008) found that past and recent synchronous recruitment trends (mid19th century, second half of the 20th century) were apparent at the tree line over the studied area of the Pyrenean range. Altitudinal treeline ecotone, growth and establishment has been occurring since the 1950s in the context of climatic warming and substantial land-use abandonment; both gradual and step-like transition patterns in tree age and size along the ecotone have been observed. GehringFasel et al. (2007) found a significant increase in forest cover between altitudes of 1650 and $2450 \mathrm{~m}$ in the Swiss Alps. Above $1650 \mathrm{~m}, 10 \%$ of the new forest areas were identified as true upward shifts, whereas $90 \%$ represented in-growth, and both land use and climate change were identified as likely drivers. Most upward shift activities occurred within a band of $300 \mathrm{~m}$ below the potential regional tree line, indicating land use as the most likely driver. Only $4 \%$ of the upward shifts were identified to rise above the potential regional tree line, thus indicating climate change. In this context, the present study aimed to (1) quantify forest dynamics in the montane-alpine belts over the past $40 \mathrm{yr}$, using 4 protected European representatives of mountain forest ecosystems; (2) investigate whether there were significant changes in forest line and forest cover; and (3) understand the relationship between these forest changes and climate modification over the past 40 to $50 \mathrm{yr}$. For this purpose, multi-temporal analysis with Landsat satellite data was performed. Regression models between forest line and cover, using baseline climate data from 1901 to 1970, were established.

\section{MATERIALS AND METHODS}

\subsection{Study areas}

The boundaries between the montane and alpine belts in 4 European mountain areas (Fig. 1) were considered for analysis. The areas shared homogeneous minimum human influence and protected status (in the core areas of national parks), and were located in the Austrian Alps, Slovak and Romanian Carpathians, and Spanish Pyrenees at similar altitudes and comparable un-forested surfaces in 1970 (pastures, alpine hollows, etc.): 19.945 ha (Ordesa, Spain), 18.945 ha (Nockberge, Austria), 10.436 ha (Tatra, Slovakia) and 15.175 ha (Retezat, Romania). The latitudinal range of the selected areas was $4^{\circ}$ (between 43 and $47^{\circ} \mathrm{N}$ ), while the general aspect (orientation) was eastern-western.

The Ordesa and Monte Perdido National Park, located in the central Pyrenees (Spain), covers 15608 ha and was established in 1918. Altitude ranges between 700 and $3355 \mathrm{~m}$ above sea level, and Monte Perdido is Europe's highest calcareous peak. Average annual rainfall is $1688 \mathrm{~mm}$, and average maximum and minimum temperatures are 8.7 and $1.5^{\circ} \mathrm{C}$, respectively (Góriz Refuge Meteorological Station at 2200 m between 1992 and 2012, both included). Natural vegetation is dominated by coniferous forest Pinus sylvestris, beech Fagus sylvatica and several oak species at lower altitudes. At higher altitudes, $P$. uncinata forests have been replaced by Buxus sempervirens, Echinospartum horridum and Juniperus communis shrublands, followed by alpine grasslands. At altitudes below $2100 \mathrm{~m}$, grasslands were created by humans to obtain pastures for livestock during summer. Since the Middle Ages, the Pyrenees forest line has been artificially lowered to increase grassland availability for livestock summer pastures (Monserrat-Martí 1992). But since 1930, a marked reduction in agro-pastoral activities in mountain areas has taken place (Alados et al. 2014, Gartzia et al. 2016b), which has also affected the Ordesa and Monte Perdido National Park, where the grazing activity was maintained as part of the conservation programme (Gartzia et al. 2016a). Consequently, we are facing important changes in the land cover in the national park, mainly below the $2100 \mathrm{~m}$, where approximately $30 \%$ of shrubland has turned to forest and $12 \%$ of grasslands have become shrubland. Above $2100 \mathrm{~m}$, the woody encroachment of grasslands is low (Gartzia et al. 2014).

The Nockberge Biosphere Park (Austria) was established initially as national park in 1987. It covers 18300 ha and is among the oldest and most interesting upland formations in Europe. Altitude ranges between 600 and $2441 \mathrm{~m}$, with the highest peak at Mt. Eisenhut in Styria $(2441 \mathrm{~m})$. The climate is continental dry, due to its central location in the European land mass. Average annual rainfall and temperature are $1100 \mathrm{~mm}$ and $7^{\circ} \mathrm{C}$, respectively. The region boasts the Eastern Alps' largest pine P. sylvestris, larch Larix decidua and spruce Picea abies forests. Wind throw is 


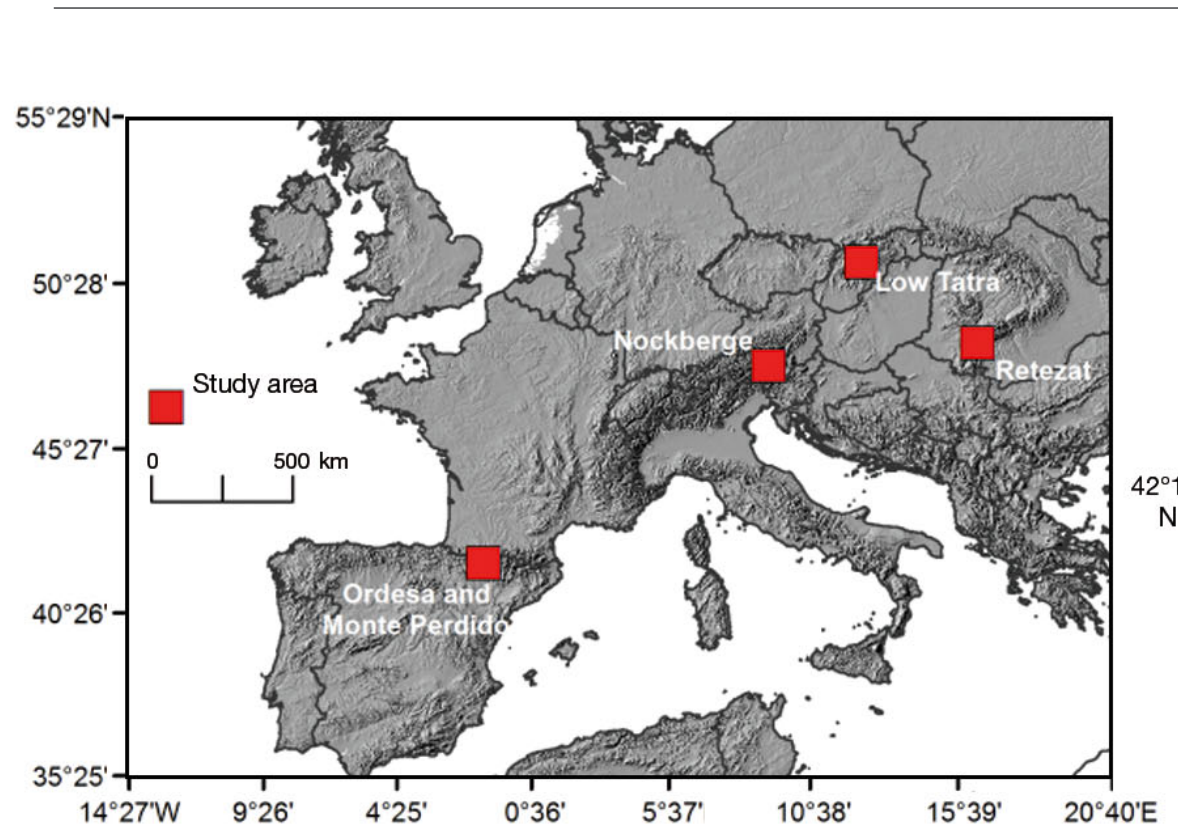

Ordesa and Monte Perdido National Park $0^{\circ} 3^{\prime} \mathrm{W}$

$0^{\circ} 58^{\prime} \mathrm{E}$
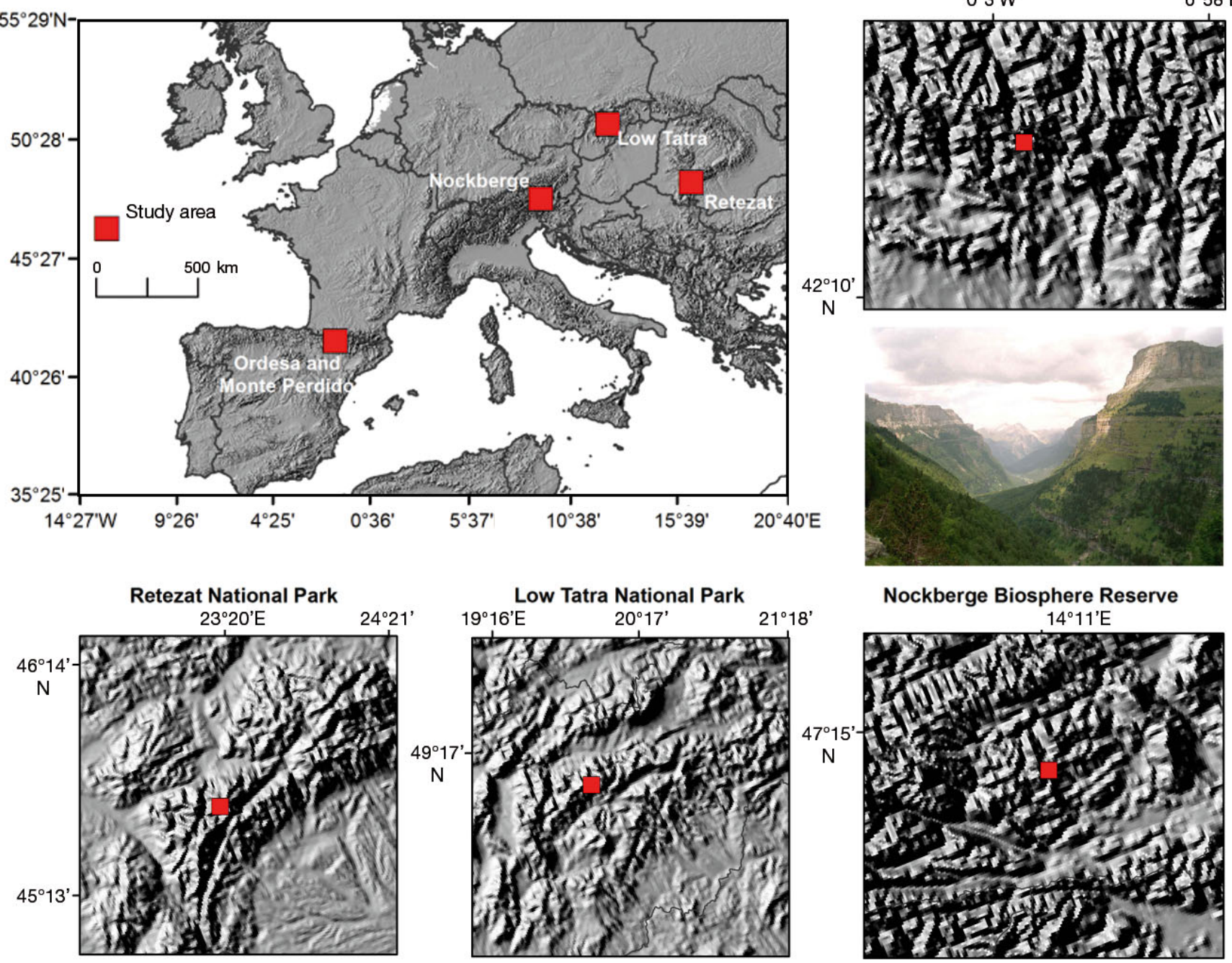

Nockberge Biosphere Reserve

$14^{\circ} 11^{\prime} \mathrm{E}$
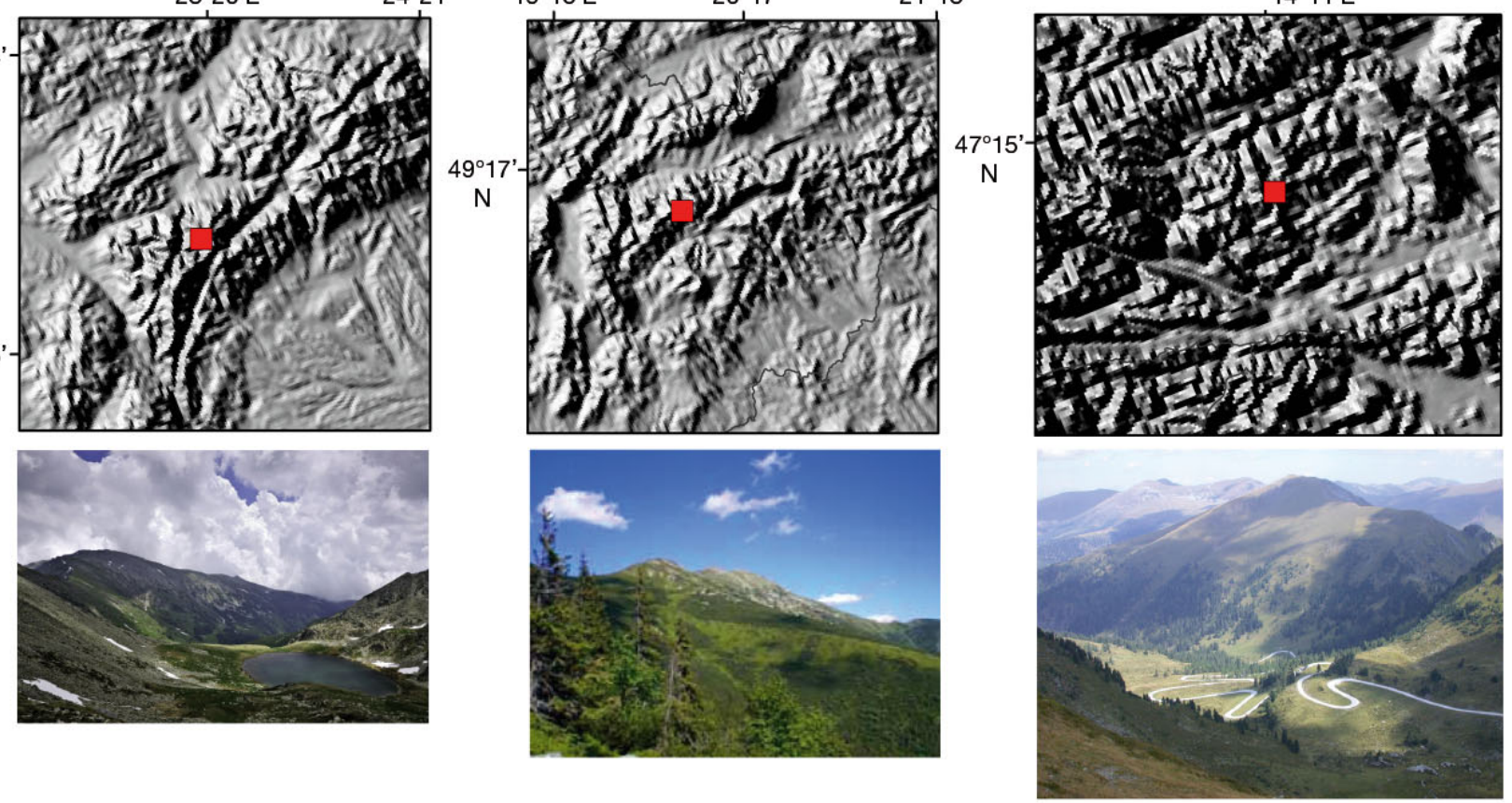

Fig. 1. Location of the mountain study sites considered in this study: Ordesa and Monte Perdido, Spanish Pyrenees; Retezat and Low Tatra in the Slovak and Romanian Carpathians; and Nockberge, Austrian Alps

the main factor that influences tree lines and their advance.

The Low Tatra National Park (Slovakia) was created in 1978 and covers 72842 ha. The first attempt to create this national park was between 1918 and 1921. Altitude ranges between 700 and $2043 \mathrm{~m}$, with the highest peak at Dumbier (2043 m). The mountains are characterised by continental mountain climate on the slopes and a slightly cold climate at the foothills. Average annual temperature is $4^{\circ} \mathrm{C}$ and average annual precipitation $1200 \mathrm{~mm}$. Dwarfed pines $P$. mugo, mountain ashes Sorbus aucuparia and small pines $P$. sylvestris occupy the park's highest areas. The constant interaction between natural forces and human effects (mainly destructive activities) has significantly influenced the tree line of the Tatra Mountains, (as well as of other important mountains regions of Slovakia). As a general rule, 
tree lines in Slovakian mountains are not situated at their natural elevation. For example, nowadays, the tree line is situated on average at altitudes of 1185 to $1430 \mathrm{~m}$. Furthermore, strong winds affected the forest stands near the tree line from the Tatra Mountains in 2004, which was followed by a damaging fire.

The Retezat National Park (Romania) was created in 1935. With an area of 38138 ha, it shelters one of Europe's last remaining intact old-growth forests and the continent's largest single area of pristine mixed forest. Altitude ranges between 600 and $2509 \mathrm{~m}$, with the highest peak at Peleaga $(2509 \mathrm{~m})$. Average annual temperature is $6^{\circ} \mathrm{C}$ and average annual precipitation is $1400 \mathrm{~mm}$. The main tree line species are Norway spruce $P$. abies, mountain pine $P$. mugo and alpine stone pine Pinus cembra. Wind throw is the main factor that influences tree lines and their advance.

\subsection{Forest line and forest cover quantification using satellite imagery data}

The tree line was defined in this study as the pixels classified as forest (according to the FAO definition) near the non-forest pixels located in the upper area of the massif. Assessing the expansion of forest line over time is a typical problem of change detection, and many approaches can be found in the literature (Singh 1989, Almutairi \& Warner 2010, Canty 2010, Hecheltjen et al. 2014), each with specific advantages and disadvantages.

Change detection methods can be grouped into 6 categories (Lu et al. 2004): algebra (which includes image differencing, vegetation indexes, change vector analysis); transformation (e.g. principal component analysis); classification; advanced models (where image reflectance values are often converted to physically based parameters); GIS approaches; and visual analysis. Generally, it is not possible to establish a priori which method of change detection is the most convenient, so the choice is often made on a pragmatic and application-driven basis (Coppin et al. 2004).

\subsubsection{Imagery pre-processing}

The Landsat Data Continuity Mission (LDCM) and the launch of the Landsat 8 platform in 2013 offer a unique opportunity to perform monitoring by remote sensing on a regional scale (Mandanici \& Bitelli 2015). Owing to the large temporal extent (19722014), remote sensing data were obtained from dif- ferent Landsat sensors: Landsat Multispectral Scanner (MSS) sensor for 1972 and 1980; Landsat Thematic Mapper (TM) sensor for 1990; Landsat Enhanced Thematic Mapper Plus (ETM+) for 2000; and Operational Land Imager (OLI) for 2014.

Sixteen Landsat scenes acquired during the vegetation season (May to September between 1973 and 2014) were used to evaluate temporal dynamics in forest lines and forest covers across the study sites. The scenes were obtained from the United States Geological Survey (USGS) repository (http://earthexplorer.usgs.gov/). In order to reduce noise caused by different acquisition angles, seasons and reflectance features, scenes captured in different years, but within the same vegetation season, were chosen for each study area. In this study, we used L1T products which, according to producer, provide a high radiometric and geodetic accuracy by incorporating ground control points while employing a digital elevation model for topographic displacement (Table 1). The spectral coverage of band images is 0.42$2.29 \mu \mathrm{m}$ for OLI, $0.45-2.35 \mu \mathrm{m}$ for ETM, 0.45-2.35 $\mu \mathrm{m}$ for TM and 0.5-1.1 $\mu \mathrm{m}$ for MSS.

As reference cartographic material we used the Soviet Topographic Map, a declassified map that was created based on intelligence information gathered in the Cold War period (Oberman \& Mazhitova 2003). The map was georeferenced based on the original Gauss-Kruger grid reprojected in Universal Transverse Mercator (UTM), World Geodetic System 1984 (WGS84) projection, with an average root mean square error of $5 \mathrm{~m}$.

\subsubsection{Image processing}

Atmospheric correction. Images acquired on different dates are affected to some extent by the presence of haze and dust in the atmosphere, a fact that could mask real changes in a given territory. In order to reduce this effect, images were corrected atmospherically using the European Cooperation in Science and Technology (COST) model developed by Chavez (1996), which employs the cosine of the solar zenith angle, representing a good approximation of atmospheric transmittance.

Topographic correction. To remove the relief effects, images were normalised using the Shuttle Radar Topographic Mission (SRTM) digital terrain model downloaded from http://earthexplorer.usgs. gov/. SRTM is a key breakthrough in digital mapping and provides a major advance in the accessibility of high-quality elevation data worldwide. 
Table 1. Summary of satellite data used for multi-temporal mapping of forest dynamics in the mountain study sites. NIR: near-infrared band; SWIR: shortwave infrared band

\begin{tabular}{|c|c|c|c|c|c|c|}
\hline \multirow[t]{2}{*}{ Year } & \multirow[t]{2}{*}{ Ordesa } & \multirow[t]{2}{*}{ Nockberge } & \multirow[t]{2}{*}{ Low Tatra } & \multirow[t]{2}{*}{ Retezat } & \multicolumn{2}{|c|}{ Metadata } \\
\hline & & & & & $\begin{array}{l}\text { Band-to-band } \\
\text { registration } \\
\text { accuracy }\end{array}$ & $\begin{array}{c}\text { Geometric } \\
\text { accuracy and } \\
\text { registration success }\end{array}$ \\
\hline 1970 & $\begin{array}{l}\text { Soviet Topo- } \\
\text { graphic Map }\end{array}$ & $\begin{array}{l}\text { Soviet Topo- } \\
\text { graphic Map }\end{array}$ & $\begin{array}{l}\text { Soviet Topo- } \\
\text { graphic Map }\end{array}$ & $\begin{array}{l}\text { Soviet Topo- } \\
\text { graphic Map }\end{array}$ & - & $5 \mathrm{~m}$ \\
\hline 1980 & $\begin{array}{c}\text { 1975-07-26 } \\
\text { GLS } 1975\end{array}$ & $\begin{array}{l}\text { 1979-05-22 } \\
\text { Landsat } 2\end{array}$ & $\begin{array}{l}\text { 1979-09-03 } \\
\text { Landsat } 2\end{array}$ & $\begin{array}{c}\text { 1980-09-21 } \\
\text { Landsat } 3\end{array}$ & $\begin{array}{l}0.2 \text { pixel } \\
(90 \%)\end{array}$ & $\begin{array}{c}<40 \mathrm{~m} \\
\text { (average } 30.6 \mathrm{~m} \text { ) }\end{array}$ \\
\hline 1990 & $\begin{array}{l}\text { 1989-07-17 } \\
\text { GLS } 1990\end{array}$ & $\begin{array}{l}\text { 1988-08-07 } \\
\text { Landsat } 5\end{array}$ & $\begin{array}{l}\text { 1990-07-16 } \\
\text { Landsat } 5\end{array}$ & $\begin{array}{c}\text { 1988-08-29 } \\
\text { Landsat } 5\end{array}$ & $\begin{array}{l}0.2 \text { pixel } \\
(90 \%)\end{array}$ & $\begin{array}{c}<30 \mathrm{~m} \\
\text { (average } 22 \mathrm{~m} \text { ) }\end{array}$ \\
\hline 2000 & $\begin{array}{l}\text { 2001-08-1 } \\
\text { Landsat } 7\end{array}$ & $\begin{array}{l}\text { 2003-06-30 } \\
\text { Landsat } 7\end{array}$ & $\begin{array}{l}\text { 2001-05-26 } \\
\text { Landsat } 7\end{array}$ & $\begin{array}{l}\text { 2000-08-22 } \\
\text { Landsat } 7\end{array}$ & $\begin{array}{l}0.2 \text { pixel } \\
(90 \%)\end{array}$ & $\begin{array}{c}<30 \mathrm{~m} \\
\text { (average } 4.6 \mathrm{~m} \text { ) }\end{array}$ \\
\hline 2014 & $\begin{array}{l}\text { 2014-07-22 } \\
\text { Landsat } 8\end{array}$ & $\begin{array}{l}\text { 2014-09-18 } \\
\text { Landsat } 8\end{array}$ & $\begin{array}{l}\text { 2014-08-03 } \\
\text { Landsat } 8\end{array}$ & $\begin{array}{l}\text { 2014-07-04 } \\
\text { Landsat } 8\end{array}$ & $\begin{array}{l}0.2 \text { pixel } \\
(90 \%)\end{array}$ & $\begin{array}{c}<30 \mathrm{~m} \\
\text { (average } 8.3 \mathrm{~m} \text { ) }\end{array}$ \\
\hline
\end{tabular}

The sun-canopy-sensor (SCS) topographic correction method was used to remove topographic effects. SCS correction (Gu \& Gillespie 1998) is based on SCS geometry and it can be expressed as:

$$
L_{m}=L \cdot\left(\frac{\cos \theta \cdot \cos \alpha}{\cos i}\right)
$$

where $L_{\mathrm{m}}$ is the normalised radiance, $L$ is the uncorrected radiance, $\theta$ is the solar zenith angle, $i$ is the incident angle and $\alpha$ is the slope of the surface.

All images have been thus co-registered to UTM, WGS84, and the accuracy of image registration was assessed using topographic plans and local cartographic products based on terrestrial measurements and aerial surveys, according to the acquisition period (Fig. 2).

Owing to the different characteristics of spectral sensors (i.e. TM and ETM+) in the Landsat image series, we also corrected the spectral reflectance between images acquired by different sensors (MSS, TM, ETM+ and OLI8). The empirical line approach for reflectance factor retrieval from Landsat-5 TM and Landsat-7 ETM+ was used for this purpose (Moran et al. 2001). All operations were performed in ENVI 5.0.

\subsubsection{Mapping and change detection in forest line and cover}

Temporal and spatial dynamics in forest covers and lines within the montane-alpine elevation belts
(>900 m) were measured using post-classification comparison (PCC) change detection with independently classified images. This method compares, pixel by pixel, 2 independent classified images acquired on different dates, using a change detection matrix (Jensen 2004). PCC minimises the influence of sensor variation in the detection of change. Results depend on the accuracy of initial classifications (Coppin \& Bauer 1996). The method locates changes and provides 'from-to' change information. Here, the source for PCC change detection was land cover data created for each Landsat scene. Land cover classification was performed using a supervised classification with maximum likelihood algorithm supported by forest management data that provided information on the spatial distribution of forest and other additional variables (e.g. stand age, height or diameter). Two land cover classes were considered (forest and pasture), and all bands were used for classification, except the thermal band. The approach included the 3 steps: training site selection, classification and assessment of results (Lillesand et al. 2008).

Reference data for training and validation were collected based on high-resolution satellite images or air photos available in Google Earth that cover the complete study area (Knorn et al. 2009, Baudron et al. 2011). We sampled 200 random training areas and classified those as either forest or non-forest, based on visual interpretation. Areas were considered forested if tree cover exceeded $60 \%$ and forest 


\section{Retezat}

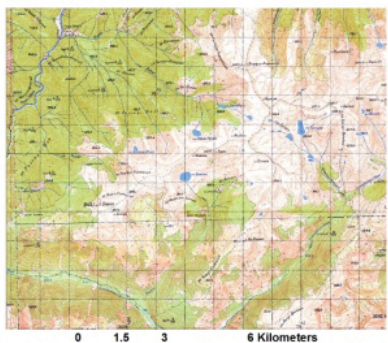

1970

1980

(4-3-2)
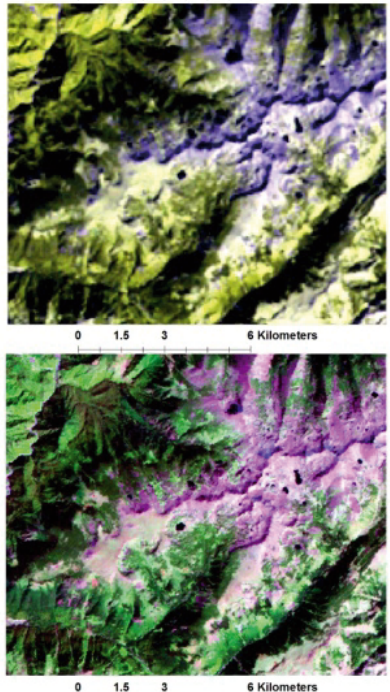

1990

(5-4-3)

2000

(7-4-3)
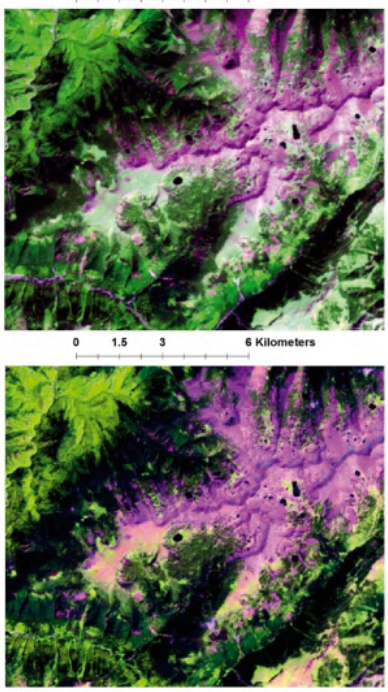

Nockberge
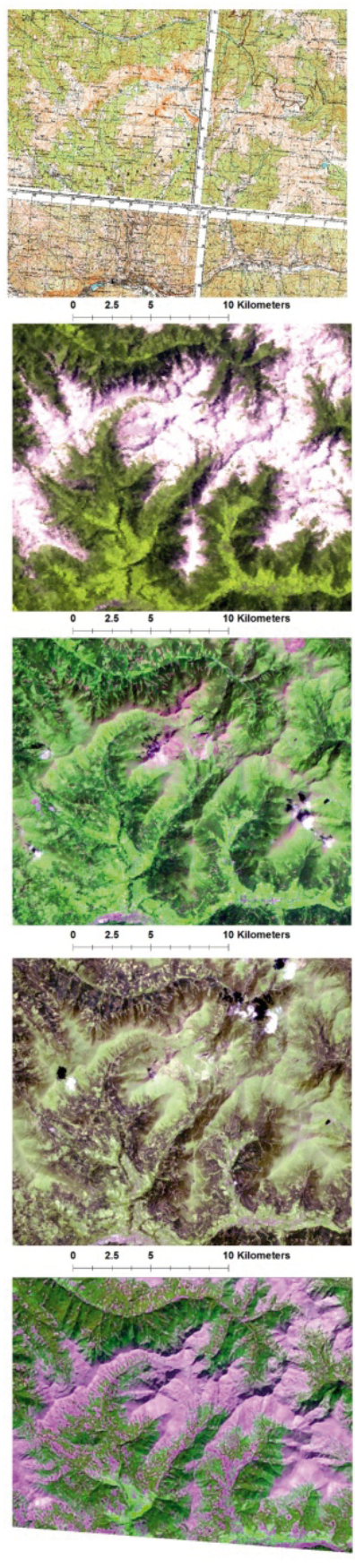

Low Tatra
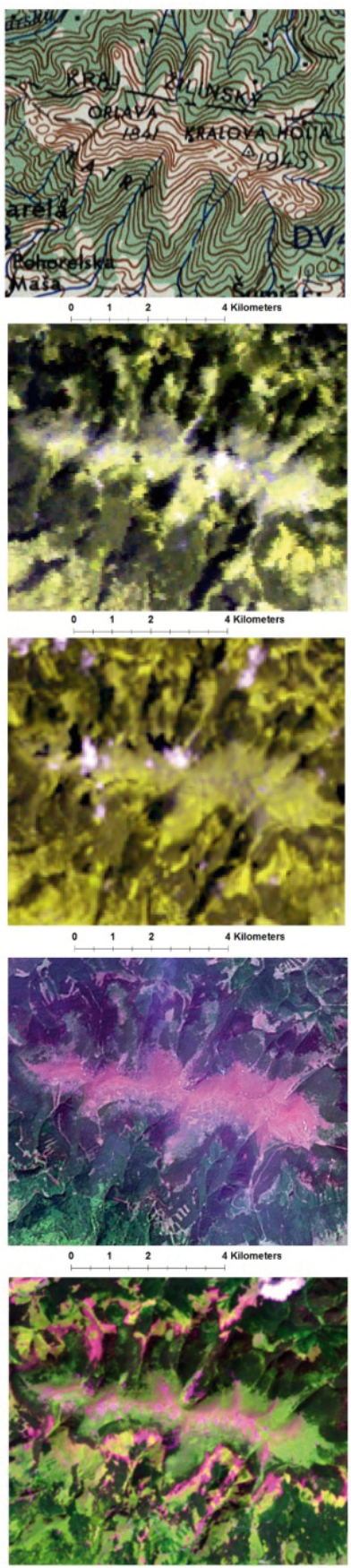

\section{Ordesa and} Monte Perdido
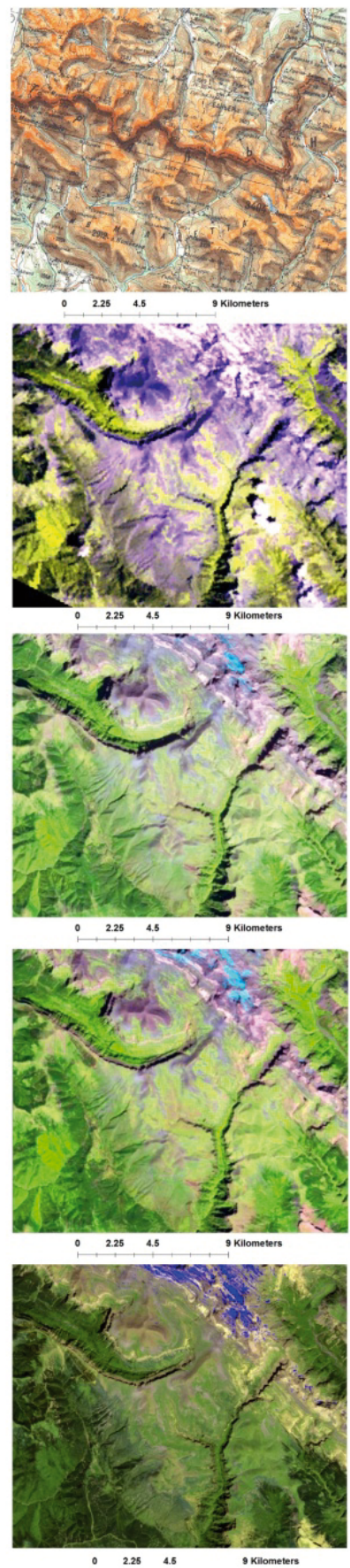

Fig. 2. Illustration of topographic maps (1970) and Landsat imagery used in the supervised mapping of forest with false colour composites: 1980 (Landsat MSS 4-3-2), 1990 (Landsat TM 5-4-3), 2000 (Landsat ETM+ 7-4-3) and 2014 (Landsat OLI 7-5-4)

patches were larger than 1 Landsat pixel $\left(900 \mathrm{~m}^{2}\right)$ (Kuemmerle et al. 2009).

Classification accuracy was evaluated through a confusion matrix based on a minimum of 100 ground truth sites for each image, other than the training sites, established through a random sampling strat- egy based on field recommendations (Congalton \& Green 2009, Vorovencii 2014). In order to emphasise the changes in land cover classes over the 1970-2014 period, the classified images were compared by cross-tabulation, which resulted in the change matrix that estimates quantitative change (Fig. 3). Using 


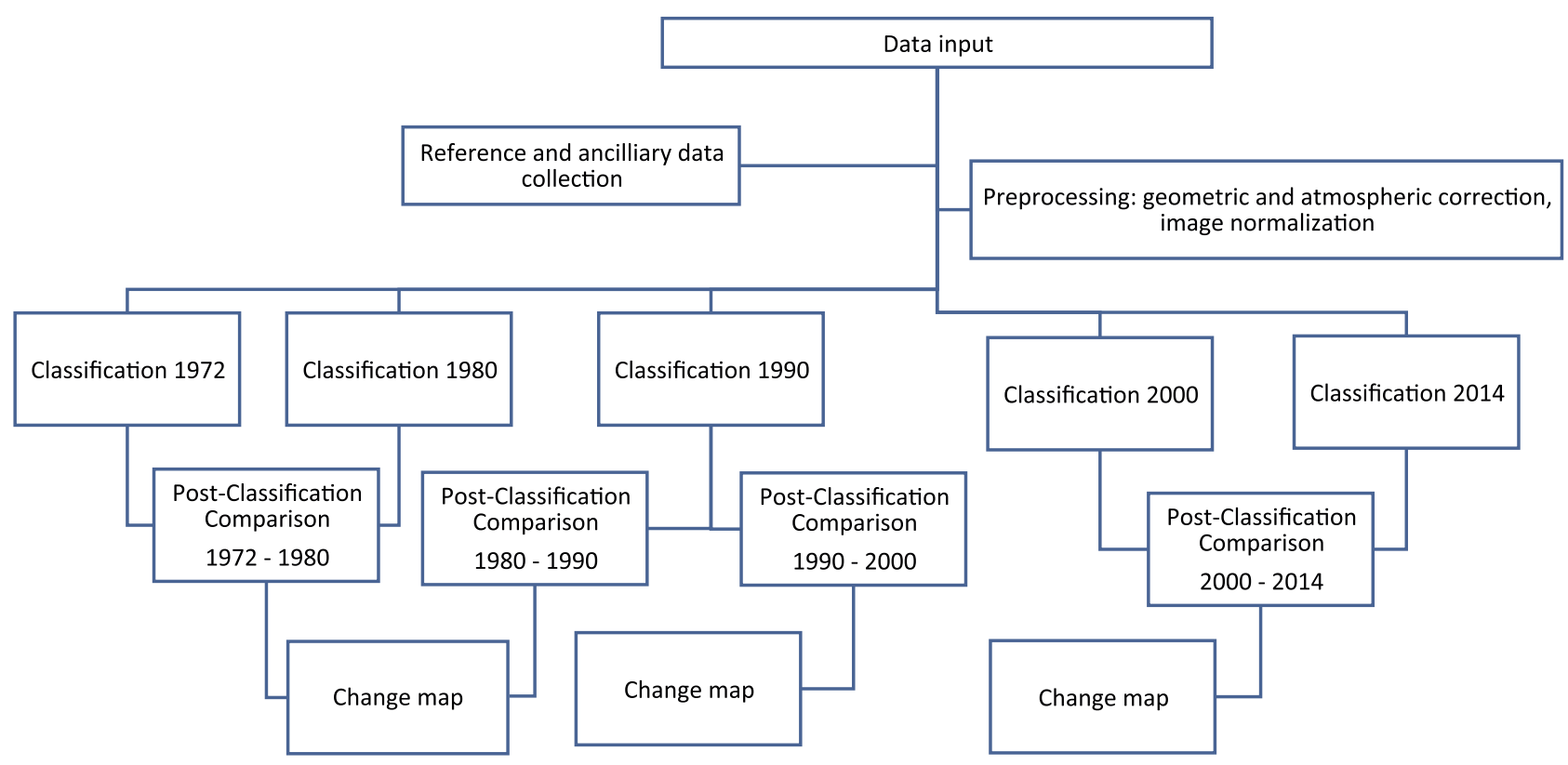

Fig. 3. Analytical framework used for multi-temporal land cover analysis across the study sites with Landsat satellite scenes

these data, forest line and forest cover dynamics were quantified (Fig. 4).

\subsection{Historical climate data}

Climate data retrieved from Climate Explorer Utility (http://climexp.knmi.nl) were used to pattern climate conditions across each study area from 1900 to 2014 (we took monthly station data, introducing the coordinates of the national parks, from the 10 nearest meteorological stations to that point). To reconstruct climate condition trends during the analysed tree line period (1970-2014), climate data between 1901 and 1970 were taken as a baseline. Climate conditions were represented by average temperature, precipitation and de Martonne aridity index (de Martonne 1926). However, preliminary correlation analysis showed an insignificant statistical relationship between growth in forest area and the last 2 variables, which led to their exclusion from the analysis. This was expected, as precipitation in forest line ecosystems is not a limiting factor (Leal et al. 2007, Grytnes et al. 2014)

\subsection{Statistical analysis}

Temperature evolution was analysed using simple graphical trends for the studied regions. The reference mean temperature values calculated as simple arithmetic means of periods covering 10 to $15 \mathrm{yr}$ each were used to plot the trends. A clear growth trend was observed, so further analyses were carried out to estimate the relationship between temperature increase and both forest cover growth and altitudinal forest line migration. The percentage of forested cover growth and the forest line altitudinal migration were plotted versus the relative temperature increment during the studied period. Furthermore, the dependence between the percentage of forest cover growth and forest line altitude migration, with respect to temperature variation in the studied period, were modelled using least-squares simple regression.

\section{RESULTS}

\subsection{Forest line and forest cover dynamics across the montane-alpine boundary}

The error matrix obtained for each land cover classification is presented in Table 2. Overall accuracy values reached the minimum average standard of $85 \%$ recommended by the USGS classification scheme (Anderson et al. 1976), which indicates a strong link between map classification and ground reference data.

The accuracy values can be grouped (Congalton \& Green 1999) into (1) strong link (>0.80; $>80 \%) ;(2)$ 

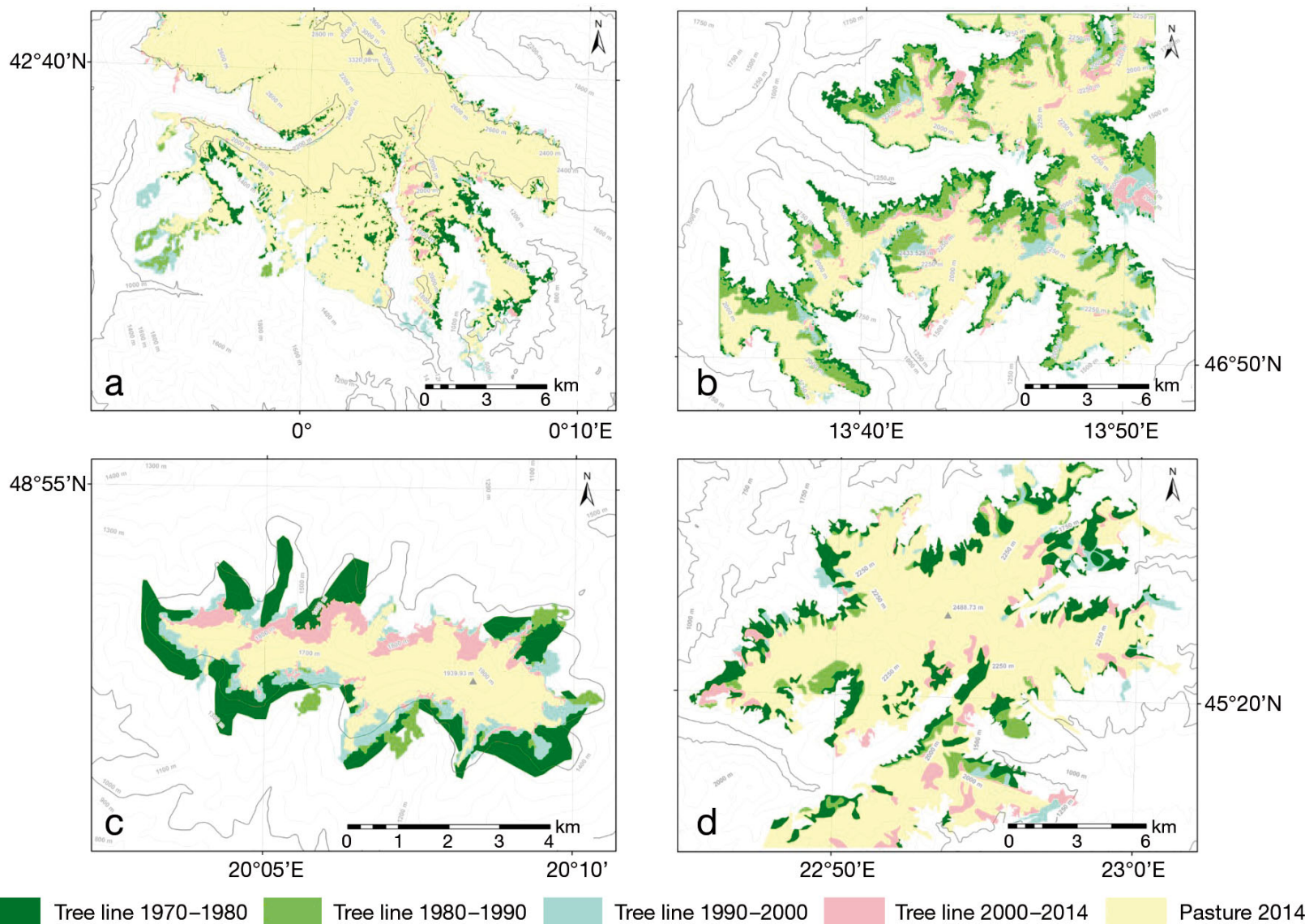

Fig. 4. Spatial and temporal dynamics of forest line and cover in 4 European mountain sites obtained from supervised land cover classification of Landsat satellite data between 1970 and 2015. Dynamics are represented using a 10 yr time-step interval for (a) Ordesa and Monte Perdido National Park, Spain; (b) Nockberge Biopshere Park, Austria; (c) Low Tatra Park, Slovakia; and (d) Retezat National Park, Romania

moderate link $(0.40-0.80 ; 40-80 \%)$; and (3) weak link $(<0.40 ;<40 \%)$.

All study sites showed changes in forest line and forest cover. Highest and lowest change in elevation of the upper forest limit (altitude growing) occurred in the Alps (Nockberge) and Pyrenees (Ordesa), respectively. Surface forest growth indicated differ- ences between sites. The largest forest expansion was registered in the Alps ( $28 \%$; Nockberge) and the lowest in the Pyrenees $(1 \%$; Ordesa) for the period 1981-1990. The largest forest line advance was recorded in the Alps (Nockberge) and the Carpathians (Retezat), while the lowest was found in the Pyrenees (Ordesa) (Table 3).

Table 2. Summary of forest class accuracies (\%) of land cover maps (see Fig. 4) obtained with maximum likelihood supervised classification of Landsat satellite data (years 1980, 1990, 2000 and 2014), along with Kappa statistics. PA: producers' accuracy;

UA: users' accuracy

\begin{tabular}{|c|c|c|c|c|c|c|c|c|}
\hline & \multicolumn{2}{|c|}{ Ordesa (ES) } & \multicolumn{2}{|c|}{ Nockberge (AU) } & \multicolumn{2}{|c|}{ Low Tatra (SK) } & \multicolumn{2}{|c|}{ Retezat (RO) } \\
\hline & PA & UA & PA & UA & PA & UA & $\mathrm{PA}$ & $\mathrm{UA}$ \\
\hline 1980 & 90 & 85.60 & 86.64 & 82.10 & 86.00 & 81.30 & 92.40 & 88.30 \\
\hline 1990 & 85 & 78.40 & 84.70 & 79.40 & 89.50 & 83.40 & 90.30 & 84.20 \\
\hline 2000 & 94 & 89.40 & 97.50 & 94.30 & 98.20 & 97.10 & 96.30 & 95.30 \\
\hline 2014 & 95 & 91.50 & 88.12 & 98.70 & 96.30 & 95.20 & 96.40 & 96.20 \\
\hline Mean & \multicolumn{2}{|c|}{86.23} & \multicolumn{2}{|c|}{88.63} & \multicolumn{2}{|c|}{89.25} & \multicolumn{2}{|c|}{91.00} \\
\hline Kappa statistics & \multicolumn{2}{|c|}{0.84} & \multicolumn{2}{|c|}{0.87} & \multicolumn{2}{|c|}{0.88} & \multicolumn{2}{|c|}{0.90} \\
\hline
\end{tabular}


Table 3. Summary of changes in forest line and forest cover across the study areas between 1970 and 2014, and average annual temperatures registered during this period

\begin{tabular}{|c|c|c|c|c|}
\hline & \multicolumn{2}{|c|}{$\begin{array}{l}\text { Forest expansion } \\
\text { (ha) }(\%)\end{array}$} & \multirow[t]{2}{*}{$\begin{array}{l}\text { Altitude } \\
\text { gain } \\
\text { (m) }\end{array}$} & \multirow[t]{2}{*}{$\begin{array}{l}\text { Temp- } \\
\text { erature } \\
\left({ }^{\circ} \mathrm{C}\right)\end{array}$} \\
\hline Ordesa & & & & \\
\hline $1901-1970$ & 0 & 0 & 0 & 4.45 \\
\hline 1971-1980 & 243 & 1.22 & 5 & 4.63 \\
\hline 1981-1990 & 195 & 0.99 & 4 & 5.25 \\
\hline $1991-2000$ & 874 & 0.48 & 18 & 5.79 \\
\hline 2001-2014 & 3034 & 1.28 & 5 & 6 \\
\hline \multicolumn{5}{|l|}{ Nockberge } \\
\hline $1901-1970$ & 0 & 0 & 0 & 4.1 \\
\hline 1971-1980 & 3204 & 16.91 & 90 & 4.29 \\
\hline 1981-1990 & 4430 & 28.14 & 44 & 4.73 \\
\hline 1991-2000 & 1601 & 14.15 & 34 & 5.29 \\
\hline 2001-2014 & 1539 & 10.03 & 2 & 5.51 \\
\hline \multicolumn{5}{|l|}{ Low Tatra } \\
\hline $1901-1970$ & 0 & 0 & 0 & 2.22 \\
\hline 1971-1980 & 181 & 12.6 & 43 & 2.41 \\
\hline 1981-1990 & 5 & 0.4 & 10 & 2.81 \\
\hline $1991-2000$ & 271 & 21.68 & 40 & 2.91 \\
\hline 2001-2014 & 183 & 18.69 & 1 & 3.62 \\
\hline \multicolumn{5}{|l|}{ Retezat } \\
\hline $1901-1970$ & 0 & 0 & 0 & 4.36 \\
\hline 1971-1980 & 1997 & 13.16 & 61 & 4.08 \\
\hline 1981-1990 & 737 & 5.67 & 13 & 4.24 \\
\hline 1991-2000 & 414 & 3.38 & 5 & 4.54 \\
\hline 2001-2014 & 962 & 8.12 & 17 & 5.25 \\
\hline
\end{tabular}

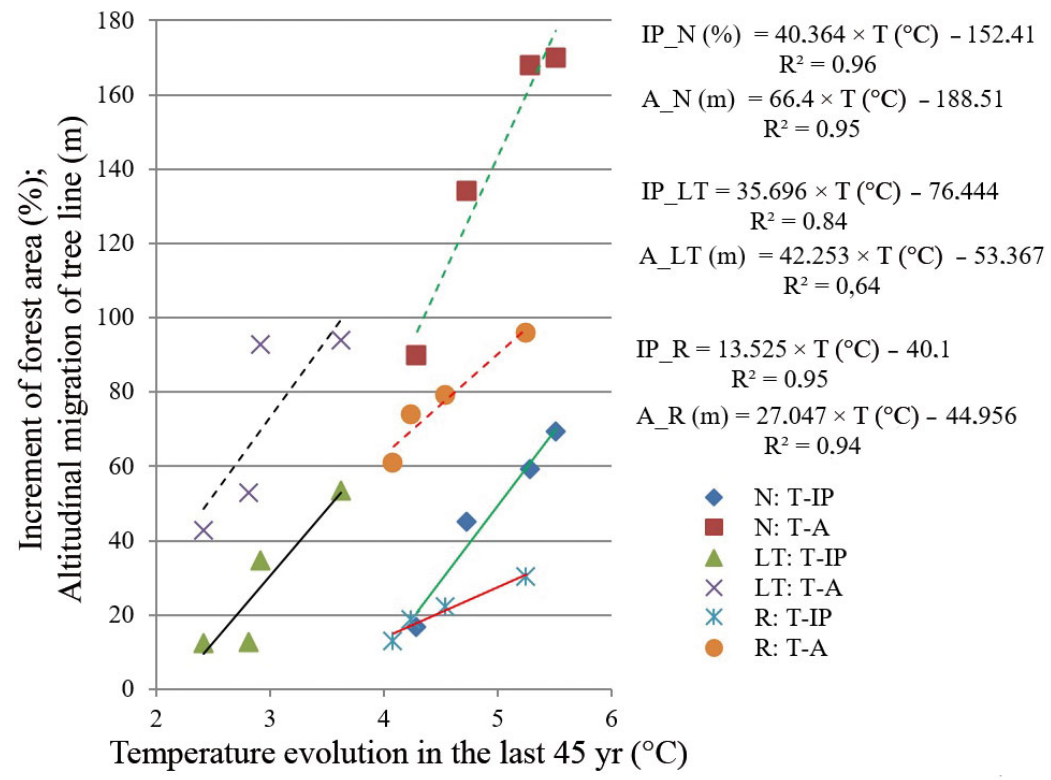

Fig. 5. Estimation equations indicating trends, relationships and intensity of dependence between the studied parameters for the 3 areas (N: Nockberge; LT: Low Tatra; R: Retezat). IP: increment percentage of forest; A: altitude; $\mathrm{T}$ : temperature
Table 4. Spatial distribution of the expansion in forest cover $(\%)$ across topographic exposure classes in the study areas

\begin{tabular}{|lccc|}
\hline \multirow{2}{*}{ Exposition } & \multicolumn{3}{c|}{ Forest area growth (\%) } \\
& Nockberge & Retezat & Low Tatra \\
\hline N & 18 & 14 & 15 \\
NE & 18 & 12 & 12 \\
E & 11 & 10 & 7 \\
SE & 6 & 11 & 20 \\
S & 5 & 9 & 22 \\
SW & 8 & 11 & 10 \\
W & 16 & 14 & 3 \\
NW & 19 & 20 & 9 \\
\hline
\end{tabular}

Forest expansion also varied across exposure classes and study sites. In the Austrian Alps (Nockberge) and the Romanian Carpathians (Retezat), expansion was strongly skewed to northerly slopes, while in the Slovakian Carpathians (Low Tatra), it occurred mostly on southerly slopes (Table 4).

\subsection{Relationship between average annual temperature and forest line and cover dynamics}

Historical climate data evidence an increase in average annual temperature between 1950 and 2014 across all sites. Overall, the average increase was $1.1^{\circ} \mathrm{C}$, with the Carpathian sites showing both the highest (Low Tatra; $+1.4^{\circ} \mathrm{C}$ ) and the lowest (Retezat; $+0.89^{\circ} \mathrm{C}$ ) increases (Fig. 5). In 3 of the studied areas, mean temperatures of the past 50 yr showed a continuously growing trend (Table 3, Fig. 5). Regression models showed strong linear relationships between forest cover increment and altitudinal migration of forest line across all sites with respect to mean annual temperature rise (Fig. 5). The increment of dependent variables had a lower magnitude in the Romanian Carpathians (Retezat), significantly contrasting with the magnitude in the Alps (Nockberge), which was the highest. Fig. 5 illustrates the magnitude of the dependencies between dependent and independent variables.

\section{DISCUSSION}

In this study, we combined multi-temporal satellite image analysis and observed the impacts of climate on forest cover and forest line dynamics in the montane-alpine 
boundary across European mountains between 1970 and 2014. Four protected areas, distributed along a west-east longitudinal gradient and enclosed in 3 emblematic European mountain ranges (Pyrenees, Alps and Carpathians), were considered. These areas were located in national parks that were created before the oldest satellite images considered for analysis. Therefore, human influence (cattle grazing, tree cutting, etc.) in the period of analysis was minimised, and changes in forest cover and line were mostly driven by natural processes. The influence of natural disruptive factors (windfalls, fires, insect attacks, etc.) was not accounted for in this study. The accuracy values of imagery classification were predominantly above the average standard $(85 \%)$ suggested by the USGS classification scheme (Anderson et al. 1976) and in line with previous studies using Landsat data in mountain regions (Kharuk et al. 2010, Hagedorn et. al 2014). Lower accuracy values in some scenes, which can slightly influence the estimations, are related to common factors influencing multi-temporal satellite studies in mountain areas (e.g. spatial resolution, atmospheric anomalies and cloud cover), including in tree line studies (Wang et al. 2006).

Forest change analysis revealed a considerable expansion in forest cover and altitudinal migration of forest lines in the montane-alpine boundary across all sites, particularly in the central eastern mountains. The expansion of forest cover and increase in altitude of the upper forest line are 2 common patterns in Northern Hemisphere mountains in the past decades (Bolli et al. 2006, Gehring-Fasel et al. 2007, Harsch et al. 2009, Schickhoff et al. 2015). Both forest cover and forest line were below their potential ranges (Gehring-Fasel et al. 2007), especially in mountains where humans have social and economic interests (Motta et al. 2006), as in the case of our study sites. The combination of atmospheric warming and decreased human activities at high altitudes promoted forest cover expansion and forest line shifts (Motta et al. 2006, Gehring-Fasel et al. 2007, Leonelli et al. 2011). Our patterns of upward shifts of the forest line were not uniform and varied across sites (Harsch et al. 2009). Registered upward shifts of forest lines were below (Low Tatra), in line with (Retezat) or above (Nockberge) the 70 to $100 \mathrm{~m}$ belt previously proposed (Moiseev et al. 2010). Forest cover expansion also differed among sites and topographic exposure. While the western forest (Pyrenees) was slightly altered, central and eastern sites showed a considerable forest cover expansion of up to $28 \%$. Dynamics in the forests of central and eastern Europe have been widely discussed in the past few years (e.g. GherigFasel et al. 2007, Hartl-Meier et al. 2014, Pretzsch et al. 2014, Munteanu et al. 2016).

The anthropogenic effect on forest expansion is reinforced by asymmetric historical distributions of the largest expansion periods across the study areas. While in the Romanian Carpathians (Retezat), large expansion occurred until the 1980s, in the Austrian Alps (Nockberg) and the Slovak Carpathians (Low Tatra), the high expansion periods were registered in and after the 1990s. Moreover, large tree line upward shifts occurred in the early 1980s. This asymmetry within study sites under the same trend (increasing average temperatures during the last century) suggests that average temperature is not the only factor impacting forest and forest line expansion. Indeed, anthropogenic activity determines European mountain tree lines (Dirnböck et al. 2003, Kuemmerle et al. 2008).

Several alpine tree line studies document altitudinal shifts and tree density increase during the 20th century (Kullman 1979, MacDonald et al. 1998), although only $51 \%$ out of 166 sites reviewed by Harsch et al. (2009) showed tree line advance. The main factors responsible for those changes were climate warming and land-use modification. In the Pyrenees, increases in temperatures between 1882 and 1970 were observed at the Pic du Midi meteorological station (Bücher \& Dessens 1991). In parallel, grazing pressure has been declining drastically since the 1950s (Alados et al. 2014). In spite of these changes, we did not observe the expected tree line upward shift. Previous studies (Camarero \& Gutiérrez 2004, Camarero et al. 2015) also show that the tree line remained static in the central Pyrenees, while tree density increased within the ecotone.

A careful reading of the overall effects of mean temperature increase on forest expansion $\left(1.31^{\circ} \mathrm{C}_{i}\right.$ 1970-2014) is therefore required (Körner 1998), as alpine vegetation can tolerate temperature increases only between 1 and $2^{\circ} \mathrm{C}$ without major changes (Theurillat \& Guisan 2001), and the response of the tree line to observed climate warming is still globally inconsistent (Harsch et al. 2009, Schickhoff et al. 2015). Nonetheless, a strong statistical relationship between tree line expansion and annual increased average temperatures was found, with sites experiencing increased temperatures showing a large advance in tree line. The temperature trend is consistent with the general constant increasing trend in average temperatures across European mountain ranges (Kullman 2007, Leonelli et al. 2011, González de Andrés et al. 2015). The impacts 
of temperature on tree lines are well known (Körner 1998), but the significant responses are mostly related to early or late growing seasons (Rammig et al. 2010, González de Andrés et al. 2015) or even winter temperatures (Kullman 2007). Our findings suggest that increasing annual average temperatures favour the expansion of tree cover and line in the Austrian Alps, Low Tatra and the Romanian Carpathians. Annual average temperatures may influence tree cover and line due (to a lesser effect) to factors affecting plant growth (e.g. wind, snow cover), improvement of microsite conditions (Leonelli et al. 2011, Pardo et al. 2013) and the favouring of seed viability and seedling emergence at higher temperatures (Kullman 2007).

In conclusion, rising mean annual temperatures in mountainous European areas have influenced tree line advance, especially in areas with reduced human intervention (national parks). This mechanism was stronger in the mountainous areas located in central Europe (Alps, Carpathians) and weaker in the warmer European areas (Pyrenees). However, uncertainty in the definition of line position suggests that interpretations should be carried out carefully. The accuracy with which the location of forest lines can be measured in historical data is influenced by the georeferencing accuracy of the data sources and the accuracy of the mapping technique in the definition of line position (Hofgaard et al. 2013). Our data include estimated uncertainties of 0.2 pixels band-toband, which indicate a relative misregistration of less than $1 / 3$ pixel in the position of forest lines due to misresgistration of Landsat imagery. In addition, uncertainty due to misclassification of forest class has also occurred. Mean uncertainty due to misclassification amounted to $11.2 \%$, with the Pyrenees (Ordesa) presenting the higher values. Interpretation in sites with limited change in forest line (e.g. Ordesa) and high uncertainty therefore requires caution.

Overall, open access to historical forest maps and multispectral satellite imagery archives combined with accurate pre-processing and classification is well suited to multi-site comparative analysis on forest line and forest cover dynamics. Comparative analysis of forest lines in protected areas can be a good strategy to better understand the response of natural systems to changes in climate conditions. The consideration of novel variables can further enhance the benefits of understanding mountain forest lines.

Acknowledgements. This article is based on work from COST Action ES1203 SensFor, supported by COST (European Cooperation in Science and Technology, www.cost.eu).

\section{LITERATURE CITED}

ACIA (2005) Arctic climate impact assessment. Cambridge University Press, Cambridge

Alados CL, Errea P, Gartzia M, Saiz H, Escós J (2014) Positive and negative feedbacks and free-scale pattern distribution in rural-population dynamics. PLOS ONE 9:e114561

Almutairi A, Warner TA (2010) Change detection accuracy and image properties: a study using simulated data. Remote Sens 2:1508-1529

Ameztegui A, Coll L, Messier C (2015) Modelling the effect of climate-induced changes in recruitment and juvenile growth on mixed-forest dynamics: the case of montanesubalpine Pyrenean ecotones. Ecol Modell 313:84-93

Anderson JR, Hardy EE, Roach JT, Witmer RE (1976) A land use and land cover classification system for use with remote sensor data. US Geological Survey Professional Paper 964. United States Government Printing Office, Washington, DC

Batllori E, Gutiérrez E (2008) Regional tree line dynamics in response to global change in the Pyrenees. J Ecol 96: 1275-1288

Baudron F, Corbeels M, Andersson JA, Sibanda M, Giller KE (2011) Delineating the drivers of waning wildlife habitat: the predominance of cotton farming on the fringe of protected areas in the mid-Zambezi valley, Zimbabwe. Biol Conserv 144:1481-1493

Baumann M, Kuemmerle T, Elbakidze M, Ozdogan M and others (2011) Patterns and drivers of post-socialist farmland abandonment in western Ukraine. Land Use Policy 28:552-562

Bolli JC, Rigling A, Bugmann H (2006) The influence of changes in climate and land-use on regeneration dynamics of Norway spruce at the tree line in the Swiss Alps. Silva Fenn 41:55-70

Bücher A, Dessens J (1991) Secular trend of surface temperature at an elevated observatory in the Pyrenees. J Climatol 4:859-868

* Cairns DM, Moen J (2004) Herbivory influences tree lines. J Ecol 92:1019-1024

* Camarero JJ, Gutiérrez E (2004) Pace and pattern of recent treeline dynamics: response of ecotones to climatic variability in the Spanish Pyrenees. Clim Change 63: 181-200

* Camarero JJ, García-Ruiz JM, Sangüesa-Barreda G, Galván JD and others (2015) Recent and intense dynamics in a formerly static Pyrenean tree line. Arct Antarct Alp Res 47:773-783

Canty MJ (2010) Image analysis, classification, and change detection in remote sensing: with algorithms for ENVI/ IDL, 2nd edn. CRC Press, Boca Raton, FL

Chavez PS Jr. (1996) Image-based atmospheric corrections - revisited and improved. Photogramm Eng Remote Sensing 62:1025-1036

* Chhetri PK, Cairns DM (2015) Contemporary and historic population structure of Abies spectabilis at treeline in Barun valley, eastern Nepal Himalaya. J Mt Sci Engl 12: 558-570

Congalton RG, Green K (1999) Assessing the accuracy of remotely sensed data: principles and practices. Lewis Publishers, Boca Raton, FL

Congalton RG, Green K (2009) Assessing the accuracy of remotely sensed data: principles and practices, 2nd edn. CRC Press Taylor \& Francis Group, London

Coppin PR, Bauer ME (1996) Digital change detection in for- 
est ecosystems with remote sensing imagery. Remote Sens Rev 13:207-234

Coppin P, Jonckheere I, Nackaerts K, Muys B, Lambin E (2004) Digital change detection methods in ecosystem monitoring: a review. Int J Remote Sens 25:1565-1596

Dalen L, Hofgaard A (2005) Differential regional treeline dynamics in the Scandes Mountains. Arct Antarct Alp Res 37:284-296

de Martonne E (1926) Areisme et indice aridite. C R Acad Sci 182:1395-1398

Dirnböck T, Dullinger S, Grabherr G (2003) A regional impact assessment of climate and land use change on alpine vegetation. J Biogeogr 30:401-417

* Galford GL, Mustard JF, Melillo J, Gendrin A, Cerri CC, Cerri CEP (2008) Wavelet analysis of MODIS time series to detect expansion and intensification of row-crop agriculture in Brazil. Remote Sens Environ 112:576-587

* Gartzia M, Alados CL, Pérez-Cabello F (2014) Assessment of the effects of biophysical and anthropogenic factors on woody plant encroachment in dense and sparse mountain grasslands based on remote sensing data. Prog Phys Geogr 38:201-217

* Gartzia M, Fillat F, Pérez-Cabello F, Alados CL (2016a) Influence of agropastoral system components on mountain grassland vulnerability estimated by connectivity loss. PLOS ONE 11:e0155193

* Gartzia M, Pérez-Cabello F, Bueno CG, Alados CL (2016b) Physiognomic and physiologic changes in mountain grasslands in response to environmental and anthropogenic factors. Appl Geogr 66:1-11

Gehrig-Fasel J, Guisan A, Zimmermann NE (2007) Tree line shifts in the Swiss Alps: climate change or land abandonment? J Veg Sci 18:571-582

González de Andrés E, Camarero J, Buntgen U (2015) Complex climate constraints of upper treeline formation in the Pyrenees. Trees (Berl) 29:941-952

* Griffiths P, Kuemmerle T, Baumann M, Radeloff V and others (2014) Forest disturbances, forest recovery and changes in forest types across the Carpathian ecoregion from 1985 to 2010 based on Landsat image composites. Remote Sens Environ 151:72-88

* Grytnes JA, Kapfer J, Jurasinski G, Birks HH and others (2014) Identifying the driving factors behind observed elevation range shifts on European mountains. Glob Ecol Biogeogr 23:876-884

Gu D, Gillespie A (1998) Topographic normalization of Landsat TM images of forest based on subpixel sun-canopysensor geometry. Remote Sens Environ 64:166-175

Hagedorn F, Shiyatov SG, Mazepa VS, Devi NM and others (2014) Treeline advances along the Urals mountain range - driven by improved winter conditions? Global Change Biol 20:3530-3543

Hansen MC, DeFries RS, Townshend JRG, Carroll M, Dimiceli C, Sohlberg RA (2003) Global percent tree cover at a spatial resolution of 500 meters: first results of the MODIS Vegetation Continuous Fields algorithm. Earth Interact 7:1-15

Hansen MC, Roy DP, Lindquist E, Adusei B, Justice CO, Altstatt A (2008) A method for integrating MODIS and Landsat data for systematic monitoring of forest cover and change in the Congo Basin. Remote Sens Environ 112:2495-2513

Harsch MA, Hulme PE, McGlone MS, Duncan RP (2009) Are tree lines advancing? A global meta-analysis of tree line response to climate warming. Ecol Lett 12:1040-1049
Hartl-Meier C, Dittmar C, Zang C, Rothe A (2014) Mountain forest growth response to climate change in the Northern Limestone Alps. Trees 28:819-829

Hecheltjen A, Thonfeld F, Menz G (2014) Recent advances in remote sensing change detection-a review. In: Manakos I, Braun M (eds) Land use and land cover mapping in Europe. Springer, Dordrecht, p 145-178

Hofgaard A, Harper KA, Golubeva E (2012) The role of the circumarctic forest-tundra ecotone for arctic biodiversity. Biodiversity 13:174-181

Hofgaard A, Tømmervik H, Rees G, Hanssen F (2013) Latitudinal forest advance in northernmost Norway since the early 20th century. J Biogeogr 40:938-949

Holtmeier FK (2009) Mountain timberlines: ecology, patchiness, and dynamics. Springer, Dordrecht

Holtmeier FK, Broll G (2005) Sensitivity and response of Northern Hemisphere altitudinal and polar treelines to environmental change at landscape and local scales. Glob Ecol Biogeogr 14:395-410

Holtmeier FK, Broll G (2007) Treeline advance-driving processes and adverse factors. Landsc Online 1:1-33

Holtmeier FK, Broll G (2010) Altitudinal and polar treelines in the Northern Hemisphere-causes and response to climate change. Polarforschung 79:139-153

Jensen JR (2004) Introductory digital image processing: a remote sensing perspective, 3rd edn. Prentice-Hall, Upper Saddle River, NJ

Jin S, Sader SA (2005) MODIS time-series imagery for forest disturbance detection and quantification of patch size effects. Remote Sens Environ 99:462-470

Kaplan JO, New M (2006) Arctic climate change with a $2{ }^{\circ} \mathrm{C}$ global warming: timing, climate patterns and vegetation change. Clim Change 79:213-241

Kharuk VI, Ranson KJ, Im ST, Vdovin AS (2010) Spatial distribution and temporal dynamics of high-elevation forest stands in southern Siberia. Global Ecol Biogeog 19:822-830

Klinge M, Böhner J, Erasmi S (2015) Modeling forest lines and forest distribution patterns with remote-sensing data in a mountainous region of semiarid central Asia. Biogeosciences 12:2893-2905

Knorn J, Rabe A, Radeloff VC, Kuemmerle T, Kozak J, Hostert P (2009) Land cover mapping of large areas using chain classification of neighboring Landsat satellite images. Remote Sens Environ 113:957-964

Körner C (1998) A re-assessment of high elevation treeline positions and their explanation. Oecologia 115:445-459

Kozak J (2010) Forest cover changes and their drivers in the Polish Carpathian Mountains since 1800. In: Nagendra $\mathrm{H}$, Southworth J (eds) Reforesting landscapes linking pattern and process. Springer, Dordrecht, p 253-273

Kuemmerle T, Hostert P, Radeloff VC, van der Linden S, Perzanowski K (2008) Cross-border comparison of postsocialist farmland abandonment in the Carpathians. Ecosystems 11:614-628

Kuemmerle T, Chaskovskyy O, Knorn J, Radeloff VC, Kruhlov I, Keeton WS, Hostert P (2009) Forest cover change and illegal logging in the Ukrainian Carpathians in the transition period from 1988 to 2007. Remote Sens Environ 113:1194-1207

Kullman L (1979) Change and stability in the altitude of the birch tree-limit in the southern Swedish Scandes 1915-1975. Acta Phytogeogr Suec 65:1-121

Kullman L (2007) Tree line population monitoring of Pinus sylvestris in the Swedish Scandes, 1973-2005: implica- 
tions for tree line theory and climate change ecology. J Ecol 95:41-52

Lambin EF, Meyfroidt P (2010) Land use transitions: socioecological feedback versus socio-economic change. Land Use Policy 27:108-118

Leal S, Melvin TM, Grabner M, Wimmer R, Briffa KR (2007) Tree-ring growth variability in the Austrian Alps: the influence of site, altitude, tree species and climate. Boreas 36:426-440

Leonelli G, Pelfini M, Morra di Cella U, Valentina Garavaglia V (2011) Climate warming and the recent tree line shift in the European Alps: the role of geomorphological factors in high-altitude sites. Ambio 40:264-273

Lillesand TM, Kiefer RW, Chipman JW (2008) Remote sensing and image interpretation. John Wiley and Sons, New York, NY

K Linderman M, Rowhani P, Benz D, Serneels S, Lambin E (2005) Land-cover change and vegetation dynamics across Africa. J Geophys Res 110:D12104

Lu D, Mausel P, Brondízio E, Moran E (2004) Change detection techniques. Int J Remote Sens 25:2365-2401

* MacDonald GM, Szeicz JM, Claricoates J, Dale KA (1998) Response of the central Canadian tree line to recent climatic changes. Ann Assoc Am Geogr 88:183-208

Mandanici E, Bitelli G (2015) Multi-image and multi-sensor change detection for long-term monitoring of arid environments with Landsat series. Remote Sens 7: 14019-14038

Mas JF (1999) Monitoring land-cover changes: a comparison of change detection techniques. Int J Remote Sens 20: 139-152

Mathisen IE, Mikheeva A, Tutubalina OV, Aune S, Hofgaard A (2014) Fifty years of tree line change in the Khibiny Mountains, Russia: advantages of combined remote sensing and dendroeological approaches. Appl Veg Sci 17: $6-16$

Moiseev PA, Bartysh AA, Nagimov ZY (2010) Climate changes and tree stand dynamics at the upper limit of their growth in the north Ural Mountains. Russ J Ecol 41: 486-497

Monserrat Martí JM (1992) Evolucion glaciar y post-glaciar del clima y la vegetacion en la vertiente sur del Pirineo: estudio palinologico. Consejo Superior de Investigaciones Cientificas. Monografias del Instituto Pirenaico de Ecologia, Vol. 6 Coop. de Artes Graficas, Zaragoza

*Moran MS, Bryant R, Thome K, Ni W and others (2001) A refined empirical line approach for reflectance factor retrieval from Landsat-5 TM and Landsat-7 ETM+. Remote Sens Environ 78:71-82

Motta R, Morales M, Nola P (2006) Human land-use, forest dynamics and tree growth at the treeline in the Western Italian Alps. Annal For Sci 63:739-747

Müller D, Kuemmerle T, Rusu M, Griffiths P (2009) Lost in transition: determinants of post-socialist cropland abandonment in Romania. J Land Use Sci 4:109-129

Munteanu C, Nita MD, Abrudan IV, Radeloff VC (2016) Historical forest management in Romania is imposing strong legacies on contemporary forests and their management. For Ecol Manage 361:179-193

* Oberman N, Mazhitova G (2003) Permafrost mapping of northeast European Russia based on the period of climatic

Editorial responsibility: Nils Chr. Stenseth, Oslo, Norway warming 1970-1995. Nor Geogr Tidsskr 57:111-120

*Pardo I, Camarero JJ, Gutiérrez E, García M (2013) Uncoupled changes in tree cover and field layer vegetation at two Pyrenean tree line ecotones over 11 years. Plant Ecol Divers 6:355-364

Payette S (2007) Contrasted dynamics of northern Labrador tree lines caused by climate change and migrational lag. Ecology 88:770-780

* Pflugmacher D, Cohen WB, Kennedy ER (2012) Using Landsat-derived disturbance history (1972-2010) to predict current forest structure. Remote Sens Environ 122: 146-165

* Potapov P, Turubanova S, Hansen MC (2011) Regional-scale boreal forest cover and change mapping using Landsat data composites for European Russia. Remote Sens Environ 115:548-561

* Pretzsch H, Biber P, Schütze G, Uhl E, Rötzer T (2014) Forest stand growth dynamics in Central Europe have accelerated since 1870. Nat Comm 5:4967

* Rammig A, Jonas T, Zimmermann NE, Rixen C (2010) Changes in alpine plant growth under future climate conditions. Biogeosciences 7:2013-2024

Schickhoff U, Bobrowski M, Böhner J, Bürzle B and others (2015) Do Himalayan tree lines respond to recent climate change? An evaluation of sensitivity indicators. Earth Syst Dynam 6:245-265

* Seto KC, Woodcock CE, Song C, Huang X, Lu J, Kaufmann RK (2002) Monitoring land-use change in the Pearl River delta using Landsat TM. Int J Remote Sens 23: 1985-2004

Shiyatov S, Terentev M, Fomin V, Zimmermann N (2007) Elevational and horizontal shifts of the upper boundaries of open and closed forests in the Polar Urals in the 20th century. Russ J Ecol 38:223-227

* Singh A (1989) Digital change detection techniques using remotely-sensed data. Int J Remote Sens 10:989-1003

* Sveinbjörnsson B, Hofgaard A, Lloyd A (2002) Natural causes of the tundra-taiga boundary. Ambio 12:23-29

*Theurillat JP, Guisan A (2001) Potential impact of climate change on vegetation in the European Alps: a review. Clim Change 50:77-109

* Townshend JR, Masek JG, Huang C, Vermote EF and others (2012) Global characterization and monitoring of forest cover using Landsat data: opportunities and challenges. Int J Digit Earth 5:373-397

Vorovencii I (2014) A change vector analysis technique for monitoring land cover changes in Copsa Mica, Romania, in the period 1985-2011. Environ Monit Assess 186: 5951-5968

* Wang T, Zhang QB, Ma KP (2006) Tree line dynamics in relation to climatic variability in the central Tianshan Mountains, northwestern China. Global Ecol Biogeogr 15:406-415

WWodcock CE, Macomber SA, Pax-Lenney M, Cohen WB (2001) Large area monitoring of temperate forest change using Landsat data: generalization across sensors, time and space. Remote Sens Environ 78:194-203

*Wulder MA, Masek JG, Cohen WB, Loveland TR, Woodcock CE (2012) Opening the archive: how free data has enabled the science and monitoring promise of Landsat. Remote Sens Environ 122:2-10

Submitted: April 8, 2016; Accepted: December 27, 2016 Proofs received from author(s): April 4, 2017 